Agro-Science Journal of Tropical Agriculture, Food, Environment and Extension Volume 9 Number 2 May 2010 pp. 70 - 75

ISSN 1119-7455

\title{
INFLUENCE OF SOIL TYPE AND FERTILIZER RATE ON THE YIELD AND YIELD STABILITY OF MAIZE IN THREE LOCATIONS OF SOUTH EASTERN NIGERIA.
}

\author{
Ezeaku P. I. \\ Department of Soil Science, Faculty of Agriculture, University of Nigeria, Nsukka, Nigeria.
}

\begin{abstract}
In a study to determine the effects of soil type and fertilizer application on maize performance and yiel d stability under rain-fed conditions, split-split-plot design was carried out using three selected locations (Nsukka, Awgu and Abakaliki) as the main plots, two cultivars of maize (Oba Super - 2 and local variety) as the sub-plot treatments, and five fertilizer levels $\left(f_{0}, f_{1} f_{2}, f_{3}, f_{4}\right)$ as the sub-subplot treatments. The treatments were replicated four times in RCB Design for three cropping seasons (1996, 1997 and 1998). Regression equations between variety mean and site mean obtained with and without fertilizer treatments were constructed. The study showed that location, fertilizer and cultivars as well as some of their interaction effects significantly, either at $\mathbf{P} \leq 0.05$ or 0.01 , affected maize yield. The significant interaction effects of location $x$ cultivar on mean grain yields suggest that under stable environmental conditions, Awgu soils emerged the best, followed by Abakaliki, and then by Nsukka. In terms of yield stability under fertilized condition the regression showed that local maize was more stable than the hybrid maize although, hybrid maize consistently out-yielded the local maize.
\end{abstract}

Key words: Soil types, fertilizer rates, Zea mays L, yield stability.

\section{INTRODUCTION}

Maize is an important staple that accounts for about $64 \%$ of the total daily caloric intake of rural people and contributes about $15.4 \%$ of protein produced by the world's crops (NRC, 1990; Fajemisin, 1985). It thrives in intercropping and relay cropping in cropping systems, and has quick biomass recovery and low economy of production (Ezeaku, 2001; Uguru and Obi, 1991). Sufficient and balanced supplies of soil nutrients particularly N, P and K elements are essential for maize production. In southeastern Nigeria, those nutrient elements have been observed to be low due to low organic matter and cation exchange capacity (Enwezor $e t$ al., 1989). For increased performance and yield of maize, 15-15-15 NPK fertilizer at the rate of $300-400 \mathrm{~kg} \mathrm{ha}^{-1}$ is commonly recommended. Incidentally, the often used NPK ratios and rates $\left(300-400 \mathrm{kgha}^{-1}\right)$ may not always be suitable to optimize crop yields in the general area of southeast Nigeria. It was, therefore, considered important to use soil information through soil analytical data to calculate appropriate fertilizer rates. Soils differ from one location to another and therefore use of a blanket recommendation rate may not satisfy the soil requirements for optimum crop performance. It is felt that fertilizer application based on soil analysis may reduce cost of production for farmers in terms of increase in efficiency of fertilizer use and reducing luxury input and luxury consumption. In an earlier study, Asadu and Enete (1997) observed that the performance of crops is generally affected by crop genotype, soil types, climate and other environmental factors. In particular, the individual contributions of edaphic factors to crop yields and stability are difficult to explain, especially if these factors vary significantly within the environment of consideration. This might be one of the reasons for the observation by Tsegaye and Hill (1996) that soil is one of the main environmental factors that determine yield. Similarly, Van Keulen and De Wit (1987) observed that environmental heterogeneity contributes considerably to production variations; hence crop ecology influence on land quality determines various levels of crop yields.

In this study, an attempt has been made to evaluate the effects of soil type and fertilizer application on maize performance and yield stability under rainfed conditions. 


\section{MATERIALS AND METHODS}

The soils of three locations (Nsukka, Awgu and Abakaliki - all of which are in the derived savanna agroecological zone of Nigeria) were studied to assess maize performance and yield stability under rainfed conditions and four fertility regimes during 1996, 1997 and 1998 cropping seasons.

The experiment at Nsukka $\left(06^{0} 52^{\prime} \mathrm{N}\right.$; $07^{0} 24^{\prime} \mathrm{E}$; 419 metres above sea level (masl) ] was conducted at the Teaching and Research Farm of University of Nigeria, Nsukka. At Awgu location $\left(06^{0} 18^{\prime} \mathrm{N}\right.$; $07^{0} 45^{\prime} \mathrm{E} ; 137$ masl), the experiment was sited in a farmer's field. The experimental site at Abakaliki $\left(06^{0} 25^{\prime} \mathrm{N}\right.$; $08^{0} 05^{\prime} \mathrm{E}$; $\left.400 \mathrm{masl}\right)$ was the Teaching and Research Farm of Ebonyi State University. The soils at Nsukka and Awgu were Ultisols, while Abakaliki soil was an Alfisols. Following the procedures in soil Taxonomy (Soil Survey Staff, 1998), Ezeaku (2000) classified the soils of Nsukka, Awgu and Abakaliki, as Typic Kandiustult, Typic Haplustult and Ultic Haplustalf, respectively.

\section{Field layout}

The experiments were conducted employing the split - split plot design. Three locations (Nsukka, Awgu and Abakaliki) were used as main plots; two maize cultivars (Oba Super-2 and a local variety) as sub plots; and five fertilizer levels $\left(\mathrm{f}_{0}, \mathrm{f}_{1}, \mathrm{f}_{2}, \mathrm{f}_{3}, \mathrm{f}_{4}\right)$ as sub-sub-plot treatments. The trials were replicated 4 times in a randomized complete block design (RCBD) for three cropping seasons in each location. The experimental units consisted of ten plots, each 6 metres long and 5 metres wide (main plot). Two maize seeds were sown in holes of $2-4 \mathrm{~cm}$ depth. Plant spacing was $0.75 \mathrm{~m}$ by $0.25 \mathrm{~m}(53,333$ plants per hectare). Fertilizer treatment application For each site, five nutrient levels were chosen; $f_{0}$ was the control treatment, while $f_{1}$ to $f_{4}$ were treatment levels. The five rates of compound NPK fertilizer applied were 0, 266, 360,493 and $627 \mathrm{kgha}^{-1}$ for Nsukka; 0, 299, 430, 566 and $700 \mathrm{kgha}^{-1}$ for Awgu, and 0, 273, 407, 540 and $674 \mathrm{kgha}^{-1}$ NPK for Abakaliki. The calculated fertilizer rates are represented by $\mathrm{f}_{1}$, $\mathrm{f}_{2}, \mathrm{f}_{3}$ and $\mathrm{f}_{4}$ levels except the control. The fertilizer treatment rates increased by $0.5,1.0$, 1.5 and 2.0 times to the initial soil data. Each location fertilizer treatment rates were arranged in a RCB Design with four replications. Fertilizer was applied to the maize by side banding at 3 weeks after planting (WAP). Maize was harvested at $16 \mathrm{WAP}$, shelled and weighed. The weight was thereafter adjusted to $14 \%$ moisture content.

Analysis of variance (ANOVA) for assessment of the various treatment effects and their interaction on the maize yield parameter was carried out by using a computer package, viz, the Statistical Analysis System (SAS, 1985). Comparison of the treatment means for significance was done by using the least significance (LSD) procedure at $5 \%$ probability level. A modified stability analysis procedure as outlined by Hilderbrand (1984) was used to test the stability of the yields. In this stability analysis, the mean yields of all the cultivars in the three locations (variety means) were regressed on the site mean. Site mean is an environmental index that determines the quality of the environment, including the management (Asadu et al., 1997). To increase the degree of freedom, the four replicate means for the three years and from the three locations (12 site means) were considered in the regression. Yields of maize from fertilized and unfertilized plots were analysed separately

\section{RESULTS AND DISCUSSION}

The result in Table 1 showed that the mean hybrid maize yields obtained in 1996, 1997 and 1998 were $3843.6,4525.8$ and $4395.7 \mathrm{kgha}^{-1}$, respectively. Similarly, the corresponding local maize mean yields for the same period were 2896.3, 3256.1 and 2945.7 $\mathrm{kgha}^{-1}$. Across the locations, fertilizers x cultivar interaction effects on the maize yield showed significance as can be seen on Table 1 . The mean yield from $\mathrm{f}_{4}$ treatment was different from the rest in 1996 except the mean yield from $\mathrm{f}_{3}$ and $\mathrm{f}_{2}$ treatments. The yields from $f_{2}$ to $f_{0}$ were similar. However, the yield from $\mathrm{f}_{3}$ was significantly $(P=0.05)$ greater than yield for $f_{1}$ treatment by $39.2 \%$, while the percentage yield difference between $\mathrm{f}_{3}$ and $\mathrm{f}_{0}$ treatments $(51.1 \%)$ was highly significant $(\mathrm{P}=0.01)$. The 1997 results showed that for hybrid maize, mean yields from $\mathrm{f}_{3}$ and $\mathrm{f}_{4}$ were significantly different from mean yields of $f_{1}$ and $\mathrm{f}_{2}$ treatments. The yields differed from that of $\mathrm{f}_{0}$ treatment. Further analysis showed that yield from $\mathrm{f}_{3}$ treatment was statistically higher than yield from $f_{1}$ and $f_{2}$ treatments by $42.4 \%$ and $24.0 \%$ respectively (Table 1). In 1998, the yields in each case obtained from $\mathrm{f}_{3}$ and $\mathrm{f}_{4}$ treatment was different from yields of $f_{2}$. Again, the yields from $\mathrm{f}_{0}$ and $\mathrm{f}_{1}$ treatments were different from that of $f_{2}$ treatment. Although, the percentage yield differences between $f_{2}$ and $f_{3}$ treatments, and between $f_{1}$ and $f_{2}$ were not significant, that of $f_{1}$ and $f_{3}(63.6 \%)$ was highly significant $(\mathrm{P} \leq 0.01)$. There were no differences between mean yields of $f_{3}$ and $f_{4}$ treatments.

It can be seen from Table 1 that the percentage variation of the crop yields decreased with crop years suggesting that yield variability of both cultivars improved with crop years. This could 
Ezeaku P. I.

be attributed to better management, reduced pest and disease attack and greater responsiveness of the two cultivars to fertilization based on soil analytical information. The effects of location, fertilizer and cultivar as well as some of their interaction on maize yield were significant (Table 2). The mean yields due to location effect showed that Abakaliki had the highest yield in 1996 followed by Awgu, while Nsukka had the lowest yields. In 1997 and 1998, Awgu soils consistently had the highest yields followed by Abakaliki and the lowest values obtained at Nsukka in both years. The combined maize yields for the three years showed that Awgu contributed the highest value $(3146.5 \mathrm{~kg} / \mathrm{ha})$, the intermediate value $\left(3112.2 \mathrm{~kg} \mathrm{ha}^{-1}\right)$ from Abakaliki and the lowest $\left(2724.7 \mathrm{~kg} \mathrm{ha}^{-1}\right)$ from Nsukka. The yield differences were larger between the Nsukka and Awgu (421.8 kg ha-1), Nsukka and Abakaliki (387.5 $\mathrm{kgha}^{-1}$ ) than Awgu and Abakaliki (34.3 kg ha-1). Thus, Nsukka was the worst location of the three in the three cropping seasons. The fertilizer effect on maize yield (Table 2) was very highly significant $(p \leq 0.01)$ in the three crop years. The yields indicated that fertilized plots consistently yielded higher than unfertilized plots. This is not unexpected and corroborates an earlier statement by Tisdale and Nelson (1975) that fertilizer is often the management factor that produces the highest increases in reference crop yields. The yield obtained due to cultivar effects (Table 2) was statistically significant $(\mathrm{p}=0.05)$. The yields for the three seasons showed that the better yielding cultivar was hybrid maize. The location $\mathrm{x}$ cultivar interaction effects on maize yields are shown in Table 3. For hybrid maize, the results show that the average yields of all plots harvested at Nsukka were 2765.5, 2867.1 and $2973.8 \mathrm{~kg} \mathrm{ha}^{-1}$ in 1996, 1997 and 1998, respectively. For the same period, the corresponding average yields of all plots harvested at Awgu were 3427.2, 3628.7 and $3718.6 \mathrm{~kg} \mathrm{ha}^{-1}$, while at Abakaliki the average yields of maize obtained for all plots were $3783.6,3288.9$ and $3380.0 \mathrm{~kg} \mathrm{ha}^{-1}$. For local maize yields, however the results of location $\mathrm{x}$ cultivar interaction effects were inconsistent in the 3 crop years.

The data on yield stability of the maize cultivars were separated and regressed to indicate those from fertilized and unfertilized plots (fig. 1). Both equations were highly significant $(\mathrm{p} \leq 0.01)$, while the degree of relationship $\left(\mathrm{R}^{2}\right)$ between the independent $(\mathrm{x})$ and response $(\mathrm{y})$ variables in the regression line was $87 \%(r=0.87)$ for hybrid maize and $92 \%(r$ $=0.92$ ) for local maize cultivar. Furthermore, the intercept and slope of the regression equation were significant $(\mathrm{p}=0.05)$. The test of significance showed the following relationships: intercept't' cal (5.3114) $\geq$ ' $t$ ' tab (2.042) and slope ' $t$ ' cal (6.23) $\geq$ ' $t$ ' tab (2.042). Also, the $95 \%$ confidence limit or interval for intercept $\left(\mathrm{L}_{1}\right.$ $=11.322$ and $\left.\mathrm{L}_{2}=13.1989\right)$ and slope $\left(\mathrm{L}_{1}=\right.$ 17.7137 and $\mathrm{L}_{2}=16.5092$ ) attest to the significance of true intercept and slope in the regression equations. Under fertilized conditions, the intercept and slope of the regression line could be used for yield predictions.

Table 1: Summary of fertilizer $x$ cultivar interaction effects on maize yield (kgha-1) Year

\begin{tabular}{|c|c|c|c|c|c|c|c|c|}
\hline \multirow{2}{*}{ Source of variation } & \multicolumn{2}{|c|}{1996} & \multicolumn{2}{|c|}{1997} & \multicolumn{2}{|c|}{1998} & \multicolumn{2}{|c|}{ Mean $(x)$} \\
\hline & hybrid & local & hybrid & local & hybrid & ocal & hybrid & local \\
\hline \multicolumn{9}{|l|}{ Fertilizer } \\
\hline $\mathrm{F}_{0}$ & 2020 & 1995.8 & 2124.9 & 2070.7 & 2370.8 & 2062.4 & 2305.5 & 2109.6 \\
\hline $\mathrm{F}_{1}$ & 2689.5 & 2479.1 & 3458.2 & 3062.4 & 3187.4 & 2070.8 & 3111.7 & 2604.1 \\
\hline $\mathrm{F}_{2}$ & 4020.7 & 2499.9 & 4562.4 & 3083.2 & 4395.7 & 3249.0 & 4326.3 & 2944.5 \\
\hline $\mathrm{F}_{3}$ & 4778.9 & 4081.5 & 6005.0 & 4458.0 & 6249.7 & 3645.7 & 5677.9 & 3061.7 \\
\hline $\mathrm{F}_{4}$ & 5208.2 & 3425.5 & 6478.9 & 3406.0 & 5874.8 & 3499.9 & 5854.0 & 3443.9 \\
\hline Mean (x) & 3843.6 & 2896.3 & 4525.8 & 3256.1 & 4395.7 & 2945.7 & - & - \\
\hline $\mathrm{CV}(\%)$ & 38.2 & 22.6 & 16.4 & 21.2 & 15.7 & 17.7 & - & - \\
\hline $\mathrm{SE} \pm$ & 734.8 & 327.0 & 371.4 & 345.4 & 344.8 & 260.9 & - & - \\
\hline LSD 0.05 & 2215.0 & 985.8 & 1119.4 & 1041.3 & 1039.3 & 786.5 & - & - \\
\hline
\end{tabular}

NB: $C V(\%)=$ Coefficient of variation percentage; SE $\pm=$ Standard error; LSD

$0.05=$ Least significant difference. $\mathrm{F}_{0}=\mathrm{Control}$ (no fertilizer), $\mathrm{F}_{1}-\mathrm{F}_{4}=$ Fertilizer treatment levels 


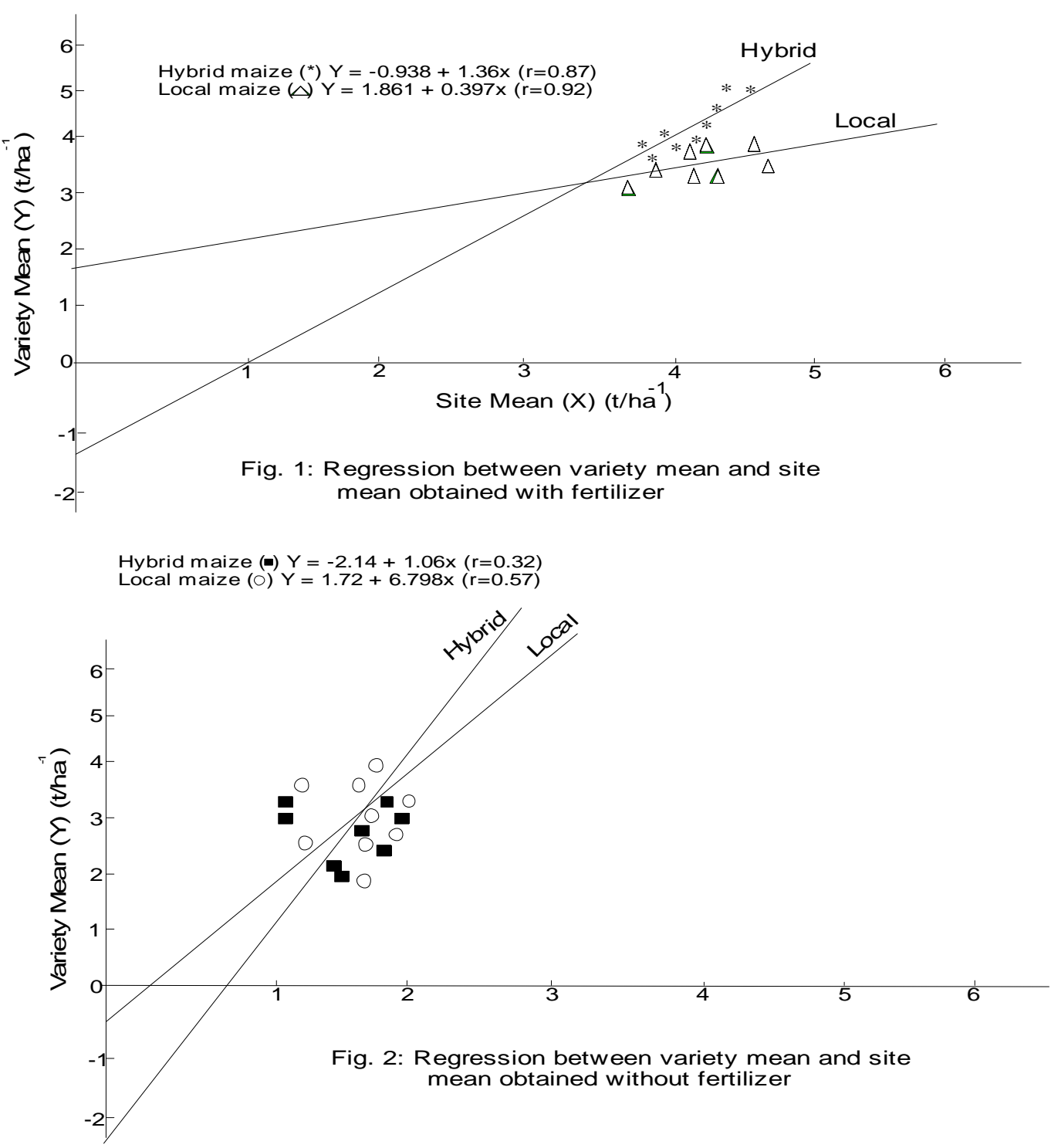

Table 2: Mean yields of maize $\left(\mathrm{kgha}^{-1}\right)$ for location, fertilizer and cultivar (Average for the three years)

\begin{tabular}{|c|c|c|c|c|}
\hline Source of variation & 1996 & 1997 & 1998 & Mean \\
\hline \multicolumn{5}{|l|}{ Location: } \\
\hline Nsukka & 2643.4 & 2744.6 & 2786.3 & 2724.7 \\
\hline Awgu & 3024.0 & 3291.9 & 3123.5 & 3146.5 \\
\hline Abakaliki & 3187.3 & 3119.4 & 3029.8 & 3112.2 \\
\hline CV (\%) & 18.3 & 17.2 & 15.6 & - \\
\hline $\mathrm{SE} \pm$ & 136.3 & 131.4 & 115.9 & - \\
\hline LSD 0.05 & 1017.0 & 891.7 & 862.9 & - \\
\hline \multicolumn{5}{|l|}{ Fertilizer: } \\
\hline NF & 2160.6 & 2242.9 & 2190.8 & 2198.1 \\
\hline $\mathrm{F}$ & 3742.5 & 3861.0 & 3768.9 & 3790.8 \\
\hline $\mathrm{SE} \pm$ & 217.1 & 158.5 & 179.3 & - \\
\hline LSD0.05 & 1153.9 & 1057.7 & 974.7 & - \\
\hline \multicolumn{5}{|l|}{ Cultivar: } \\
\hline Hybrid & 3325.4 & 3261.6 & 3357.5 & 3314.8 \\
\hline Local & 2577.7 & 2842.3 & 2602.3 & 2674.1 \\
\hline $\mathrm{SE} \pm$ & 104.2 & 98.9 & 92.8 & - \\
\hline LSD 0.05 & 877.5 & 693.6 & 711.3 & - \\
\hline
\end{tabular}

Year NB: CV $(\%)=$ Coefficient of variation percentage; $\mathrm{SE} \pm=$ Standard error; $\mathrm{NF}=$ no fertilizer; $\mathrm{F}=$ Fertilizer. 
Ezeaku P. I.

Table 3: Location $x$ cultivar interaction effects on maize mean yield $\left(\mathrm{kgha}^{-1}\right)$

\begin{tabular}{|c|c|c|c|c|c|c|c|c|}
\hline \multirow[b]{2}{*}{ Source of variation } & \multicolumn{2}{|c|}{$\underline{1996}$} & \multicolumn{2}{|c|}{1997} & \multicolumn{2}{|c|}{1998} & \multicolumn{2}{|c|}{ Mean (x) } \\
\hline & hybrid & local & hybrid & $\overline{1}$ ocal & hybrid & local & hybrid & local \\
\hline \multicolumn{9}{|l|}{ Location } \\
\hline Nsukka & 2765.5 & 2321.3 & 2867.1 & 2622.1 & 2973.8 & 2598.8 & 2868.8 & 2580.7 \\
\hline Awgu & 3427.2 & 2620.9 & 3628.7 & 2955.1 & 3718.6 & 2528.5 & 3591.5 & 2701.5 \\
\hline Abakaliki & 3783.6 & 2529.3 & 3288.9 & 2949.8 & 3380.0 & 2679.6 & 3484.2 & 2740.1 \\
\hline $\mathrm{SE} \pm$ & 258.2 & 242.2 & 308.2 & 177.9 & 285.4 & 183.7 & - & - \\
\hline LSD 0.05 & 736.9 & 693.2 & 882.4 & 507.7 & 818.4 & 524.3 & - & - \\
\hline
\end{tabular}

Although the yield of hybrid maize was higher than the local cultivar, Fig.1 showed that under fertilized conditions, hybrid maize had the most unstable yield while local maize under similar conditions gave the most stable yield. Similar observations have been made earlier by Asadu et al (1997) and Bacusmo et al (1988) on yam and sweet potato crops, respectively. The regression equations obtained for yield stability on unfertilized conditions are shown in Fig. 2. The test of significance showed that the intercept and slope in the regression equation for hybrid maize were not significant. For local maize, both intercept and slope were significant at $\mathrm{p}=0.05$.

The interaction between the site mean and variety mean in the regression (Fig. 2) showed that local maize was more stable than hybrid cultivar even-though the latter had higher yields. The linear relationship between the two variables $\mathrm{x}$ and $\mathrm{y}$ or regression lines (Figs. 1 and 2) suggest that with improvement in the quality of the environment (for example, any unit increase of inorganic fertilizers) would have a corresponding increase in the yield of both cultivar but more with hybrid maize.

\section{CONCLUSION}

The results of this study revealed that maize yields in all locations were significantly increased with increase in compound NPK fertilizer application, the magnitude of response for specific growing seasons being dependent on rainfall distribution and nutrient release ability of the soil. The response magnitude was highest at Awgu, followed by Abakaliki and lowest at Nsukka. So long as the application of fertilizer rate and method are such that minimizes unfavorable soil reaction and nutrient losses, fertilizer recommendations purely from soil analytical data would give good yield response and stability of maize in the locations studied. Even-though, the highest yielding cultivar may not always be the most stable as revealed by the present study both cultivars appeared to have great potentials in terms of their physiologic features.

\section{REFERENCES}

Asadu, C.L.A. and A.A. Enete. 1997. Food crop yields and soil properties under population pressure in sub-Saharan Africa. The case of cassava in SEN. Outlook on Agriculture, 26(1): 29-34.

Bacusmo, J.A., Collins, W.W. and U. Jones 1988. Comparison of methods of determining stability and adaptability of sweet potato. Theoretical and Applied Genetics, 75:492-497.

Enwezor, W.O., Udo, E.J., Usoro, N.J., Ayoade, K.A., Adepetu, J.A., Chude, V.O. and C.I. Ugbede. 1989. Fertilizer use and management practices for crops in Nigeria (Series No. 2) FDA, Lagos, pp. 20-45.

Ezeaku, P.I. 2000. The applicability of two concepts of land evaluation to the soils of southeastern Nigeria. Ph.D. Thesis, University of Nigeria, Nsukka, 277pp.

Ezeaku, P.I. 2001. Evaluation of legume crops as alternative source of fertilizer for maize production in Abakaliki, southeastern Nigeria. Journal of Agriculture, Technology and Extension, 6(3): 1-10.

Fajemisin, J.M. 1985. The status of maize production technology in Nigeria and prospects for sustainable selfsufficiency. Paper presented at NAFPP $3^{\text {rd }}$ Joint Workshop, Owerri, Imo State, Nigeria. March 3-9, 33pp.

Finlay, K.W. and G.N. Wilson. 1963. The analysis of adaptation in a plant breeding programme. Australian Journal of Agric. Research 14:742-754.

Hilderbrand, P.E. 1984. Modified stability analysis for farmer managed, on-farm trials. Agron. J. 76:271-274.

Obi I.U. 1986. Statistics for Agricultural Students. $1^{\text {st }}$ Ed. Optical Computer solutiona Ltd Abgani Road, Enugu, 105pp..

National Research Council (NRC) 1990. The Improvement of Tropical and Subtropical Rangelands. BOSTID, National Academy Press. Washington DC. Pp. 98-101. 
Statistical Analysis System (SAS) 1985. SAS User's Guide. Statistics Version $5^{\text {th }}$ Edition, SAS Inst. Inc. North Carolina, U.S.A. Soil Survey Staff, 1998. Keys to Soil Taxonomy, Revised $8^{\text {th }}$ Edition.

Tsegaye, T. and R. Hill. 1996. Wheel traffic placement effects on corn response under no- tillage and conventional tillage. J. Production Agric. 9:95-101.

Tisdale, S and W. Nelson. 1975. Soil fertility and fertilizer. Edition. Macmillan, New York.
Uguru, M.I. and I.U Obi, 1991. Optimum rates of NPK for hybrid maize (Zea mays $L$ ) production in the derived savanna zone of South eastern Nigeria. Nigerian Agric. Journal 25:38-46.

Van Keulen, H. and C.I. De Wit. 1987. Modeling of production of field crops and its requirements. Geoderma. 40:253-263. 